\title{
Effect of Pre-Harvest Management Practices on the Postharvest Vase Life of Cut Tuberose cv. Suvasini
}

\author{
T. Suseela, V. Vijaya Bhaskar*, R. Chandrasekhar and K. Umakrishna \\ ${ }^{1}$ Department of Floriculture and Landscape Architecture, College of Horticulture, Dr. Y.S.R. \\ Horticultural University, Venkataramannagudem - 534 101, West Godavari district, \\ Andhra Pradesh, India \\ ${ }^{2}$ Department of Floriculture and Landscape Architecture, College of Horticulture, Dr. Y.S.R. \\ Horticultural University, Anantharajupeta - 516 105, Kadapa district, Andhra Pradesh, India \\ *Corresponding author
}

\section{A B S T R A C T}

\begin{tabular}{|c|c|}
\hline $\begin{array}{l}\text { Tuberose, Sucrose, } \\
\text { Aluminium sulphate, } \\
\text { Water uptake, Fresh } \\
\text { weight, Vase life. }\end{array}$ & $\begin{array}{l}\text { An investigation was carried out to study the effect of various pre-harvest management } \\
\text { practices on the postharvest vase life of tuberose cv. Suvasini. Flower spikes harvested } \\
\text { from different pre-treated were kept in a common vase solution containing Sucrose } 4 \% \text { in } \\
\text { combination with } \mathrm{Al}_{2}\left(\mathrm{SO}_{4}\right)_{3} 500 \mathrm{ppm} \text {. Foliar application of } \mathrm{GA}_{3} 250 \mathrm{ppm} \text { recorded } \\
\text { significantly highest mean water uptake }(16.47 \mathrm{~g}) \text { followed by application of RDF } 50 \% \text { in }\end{array}$ \\
\hline Article Info & aspiration loss of water $(15.06 \mathrm{~g})$, significantly improved water balance $(15.55 \mathrm{~g})$ and \\
\hline $\begin{array}{l}\text { Accepted: } \\
19 \text { October } 2017 \\
\text { Available Online: } \\
10 \text { December } 2017\end{array}$ & $\begin{array}{l}\text { significantly highest fresh weight change of flower spike }(78.48 \mathrm{~g}) \text { and reduced rate of } \\
\text { electrolytes leakage have been recorded by application of RDF } 50 \% \text { in combination with } \\
\text { Poultry Manure } 50 \% \text { which have ultimately contributed to an increase in the per cent of } \\
\text { opened florets as well as vase life ( } 13.46 \text { days) of cut tuberose flower spikes. }\end{array}$ \\
\hline
\end{tabular}

\section{Introduction}

Tuberose (Polianthes tuberosa L.) is one of the most beautiful bulbous tropical flowering plant belonging to the family Amaryllidaceae. Flower spikes are excellent material for the decoration of vase and other floral art crafts. The flower spikes generally have a vase life of about 10 days when they are kept in the vase solution containing a floral preservative (Sadhu and Bose, 1978). Increasing the vase life of flower spikes with good quality is very important in the commercial point of view. The vase life of cut flower denotes the total duration of time it is severed from the mother plant to the wilting of flowers which depends on its water relations (Halevy and Mayak, 1981, van Doorn, 2004). The major limiting factor in the vase life of many cut flowers is water stress which creates disturbances in the water relations of cut flowers thereby changes occur in the physiology and biochemistry of flowers leading to senescence (Wakada et al., 1984). Keeping quality of cut flowers can be achieved through proper postharvest handling techniques which include use of certain chemicals in order to maintain positive water relations (Halevy and Mayak, 1979 and 1981) in the floral tissue. Among the chemicals, sucrose has been known to act as an 
oxidisable respiratory substrate thereby promoting the normal development of cut flowers and reducing changes in the petal colour and proteolytic breakdown (Larsen and Froehlich, 1969). Exogenous supply of sucrose balances the depletion of carbohydrates and improves the quality and vase life of many cut flowers (van Doorn, 2004). Aluminium sulphate is considered as an antimicrobial agent and was found to be used widely for enhancing the keeping quality of several cut flowers including rose, tuberose, carnation, gerbera, etc. (Mayak et al., 1973; Mukhopadhyay, 1982; Das, 1988). Studies with the influence of pre-harvest management practices on the postharvest vase life of tuberose flowers was found meagre excepting the studies conducted by Padaganur et al., (2005), Kumar et al., (2007) and Varu and Barad (2008). Hence, the present investigation was carried out to find out the influence of pre-harvest management practices on the postharvest vase life of cut tuberose cv. Suvasini.

\section{Materials and Methods}

The present investigation was carried out at College of Horticulture, Venkataramanna Gudem during the year 2013-2014 with field experiments laid out in factorial randomized block design followed by evaluation of cut tuberose flower spikes for their postharvest vase life in a completely randomized design with factorial concept. Based on the performance of three field experiments, the best two treatments from each experiment were used as treatments in the postharvest evaluation of tuberose flower spikes to find out the pre-harvest treatment influence on the postharvest life of cut tuberoses. The details of the treatments were as follows. The best two treatments from the experiment on the effect of spacing, bulb size and depth of planting on the vegetative and floral characters were $T_{1}: 30 \mathrm{~cm}$ x $30 \mathrm{~cm}$ spacing +
$>3.0 \mathrm{~cm}$ bulb diameter $+6.0 \mathrm{~cm}$ depth of sowing; $\mathrm{T}_{2}: 45 \mathrm{~cm} \times 30 \mathrm{~cm}$ spacing $+>3.0 \mathrm{~cm}$ bulb diameter $+6.0 \mathrm{~cm}$ depth of sowing; the best two treatments from the experiment on effect of growth regulators on the vegetative and floral characters were $\mathrm{T}_{3}$ : Foliar spraying of $\mathrm{GA}_{3} 250 \mathrm{ppm}$; $\mathrm{T}_{4}$ : Foliar spraying of NAA $250 \mathrm{ppm}$; the best two treatments from the experiment on the effect of organic manures, fertilizers and micronutrients on the vegetative and floral characters were $\mathrm{T}_{5}$ : RDF $50 \%+$ Poultry Manure 50\%; $\mathrm{T}_{6}$ : RDF $50 \%+$ Poultry Manure 25\% + Neem Cake 25\% and $\mathrm{T}_{7}$ : Control. All the treatments were replicated thrice and all the treatments contained the same holding solution of Sucrose $4 \%$ in combination with Aluminum Sulphate 500 ppm (Varu and Barad, 2008). Uniform sized flower spikes of $65 \mathrm{~cm}$ length were harvested when one or two lower most florets were ready to open on the day of harvest. The spikes were harvested early in the morning and immediately brought to the laboratory after putting them in a bucket containing water up to $20 \mathrm{~cm}$ of the base. Lower most leaves of the spikes were removed and the basal $1 \mathrm{~cm}$ portion was re-cut under water before placing them in the holding solution. After recording fresh weight, the spikes were placed in $500 \mathrm{ml}$ conical flask containing 300 $\mathrm{ml}$ of holding solution. Solution was prepared with distilled water and freshly prepared solutions were used in the experimentation. The experiment was conducted at normal room temperature $\left(26+1{ }^{\circ} \mathrm{C}\right)$, relative humidity $(65+4 \%)$ in the laboratory and the light intensity measured during the period of experimentation was recorded as $0.38 \mathrm{Wm}^{-2}$ illumination for 12 hours photoperiod. All the parameters were recorded at every two days interval during the period of vase life experimentation. Water uptake, transpiration loss of water and fresh weight of the spike were measured and expressed in grams, whereas the water balance in the tissue of flower spike was calculated by deducting the 
total transpiration loss of water from the water uptake. Further, the water loss to uptake ratio was calculated by using the formula Water loss to uptake ratio $=$ Transpiration loss of water / Water uptake. The number of opened florets was expressed in per cent, electrolytic leakage was estimated by the method described by Poovaiah (1973). Vase life was calculated by considering the number of days taken for withering and senescence of more than 50 per cent of the florets. The results obtained from the experiment were subjected to statistical analysis of variance for completely randomized design as described by Panse and Sukhatme (1985). The appropriate standard error of deviation $(\mathrm{SEd}+)$ was calculated in each case and the critical difference (CD) at five per cent level of significance was worked out.

\section{Results and Discussion}

All the parameters recorded in the postharvest study of tuberose cv. Suvasini were found significantly different with different preharvest management practices on the postharvest vase life of cut tuberose during all the days of observations recorded. The data presented in Table 1 has displayed that foliar application of $\mathrm{GA}_{3}$ at $250 \mathrm{ppm}$ concentration recorded significantly highest water uptake $(16.47 \mathrm{~g})$ followed by application of RDF $50 \%$ in combination with Poultry Manure $50 \%$ (14.79 g), whereas, control recorded significantly lowest water uptake $(6.26 \mathrm{~g})$. Among the days, significantly highest water uptake was observed on day 2 (32.48 g), whereas, significantly lowest water uptake $(0.87 \mathrm{~g})$ was observed on day 10 . The interaction effect between days and treatments was found significantly highest by application of $\mathrm{GA}_{3}$ at $250 \mathrm{ppm}$ concentration on day 2 and 4 (38.60 and $21.13 \mathrm{~g}$ respectively), whereas on day 6,8 and 10 RDF $50 \%$ in combination with Poultry Manure $50 \%$ has recorded significantly highest water uptake
(14.90, 5.63 and $2.10 \mathrm{~g}$ respectively) followed by $\mathrm{GA}_{3}$ at $250 \mathrm{ppm}$. Flowers collected from RDF $50 \%$ in combination with Poultry Manure $50 \%$ and foliar application of $\mathrm{GA}_{3}$ $250 \mathrm{ppm}$ might have exerted the improved physiological efficacy of plant thereby an improvement in the rate of photosynthesis might have been recorded due to presence of more number of leaves thereby increased leaf area index and total chlorophyll content which might have led to accumulation of more respirable substances in the floral tissue. Improved water uptake also might be due to the synergistic effect of the holding solution containing Sucrose and $\mathrm{Al}_{2}\left(\mathrm{SO}_{4}\right)_{3}$. Increased rate of water uptake in the floral tissue might be due to the presence of accumulated sugars in the floral tissue and further an increase in the osmotic potential might have improved the ability of spikes to absorb more water. Presence of $\mathrm{Al}_{2}\left(\mathrm{SO}_{4}\right)_{3}$ in the solution might have decreased the $\mathrm{P}^{\mathrm{H}}$ of solution which acidifies the holding solution, thus reduces the bacterial growth there by an increase in the rate of water uptake recorded. Similar kind of observation was reported earlier by Anjupal and Srivastava (2003) and Lal et al., (1990) in gladiolus, Saini et al., (1994) and Kumar and Singh (2004) in tuberose.

The data presented in Table 1 with regard to foliar application of $\mathrm{GA}_{3} 250 \mathrm{ppm}$ recorded significantly highest transpiration loss of water $(20.16 \mathrm{~g})$ followed by application of RDF $50 \%$ in combination with Poultry Manure 50\%, whereas, control recorded significantly lowest transpiration loss of water (8.32 g). Among the days, significantly highest transpiration loss of water was observed on day 2 (17.60 g), whereas, significantly lowest transpiration loss of water (9.83 g) was observed on day 10 . Interaction effect between treatments and days was observed significant. Flower spikes harvested from foliar application of $\mathrm{GA}_{3} 250 \mathrm{ppm}$ recorded significantly highest transpiration 
loss of water on day 2, 4, 6, 8 and 10 (26.85, 21.60, 20.2018 .77 and $13.40 \mathrm{~g}$ respectively), whereas, control recorded significantly lowest rate of transpiration loss of water on all the days of vase life period. Application of RDF $50 \%$ in combination with Poultry Manure $50 \%$ showed a positive effect in recording moderate/normal rate of transpiration loss of water which might be due to partial closure of stomata. In flower crops normal rate of transpiration is essential for extending the vase life of cut flowers and any process that hinder the normal rate of transpiration will lead to a decrease in the keeping quality of flowers (Krishnappa et al., 2004; Barman and Rajni, 2006). Varu and Barad (2008) reported that addition of aluminium sulphate and sucrose in the vase water might have led to reduced rate of transpiration mainly due to partial closure of stomata in tuberose flower petals.

Significant differences were observed in the water balance of cut tuberose (Table 2) cv. Suvasini with different pre-harvest imposition of treatments while evaluating their influence on the postharvest vase life. Among the treatments, application of RDF $50 \%$ in combination with Poultry Manure 50\% has recorded significantly highest $(15.55 \mathrm{~g})$ water balance, whereas, foliar application of $\mathrm{GA}_{3}$ $250 \mathrm{ppm}$ recorded significantly lowest water balance $(10.98 \mathrm{~g})$. Among the days, significantly highest water balance was observed on day 2 (30.23 g), whereas, significantly lowest water balance was observed on day 10 (6.54 g). Interaction effect between treatments and days was found significant. Among the treatments application of RDF $50 \%$ in combination with Poultry Manure $50 \%$ has recorded significantly highest water balance on all the days of postharvest study when compared with all other treatments. Water balance decreased significantly at each successive interval of observation recorded from day 2 to 10 .
Application of RDF 50\% in combination with Poultry Manure 50\% might have increased the physiological efficiency of flower spikes by increasing nutrient and water uptake which led to proper development of water conducting tissue. Further, increased water balance might be due to increased rate of water uptake and reduced rate of transpiration loss of water (Table 1). Nagaraja and Gowda (1998) and Panwar et al., (2006) also reported similar kind of observations which were in confirmity with the present results.

The data presented in Table 2 has indicated that significant differences were observed in the water loss to uptake ratio of cut tuberose spikes pre-treated with different field treatments to evaluate their influence on the postharvest vase life. Among the treatments, application of RDF 50\% in combination with Poultry Manure $50 \%$ has recorded significantly lowest water loss to uptake ratio (2.14) followed by foliar application of $\mathrm{GA}_{3}$ 250 ppm (3.06). Among the days, significantly lowest water loss to uptake ratio was observed on day 2 (0.56), whereas, day 10 has recorded significantly highest water loss to uptake ratio (21.19). Interaction effect between treatments and days was found significant with regard to water loss to uptake ratio. Application of RDF 50\% in combination with Poultry Manure $50 \%$ has recorded significantly lowest water loss to uptake ratio on all the days of observation recorded in comparison to all other treatments followed by foliar spraying of $\mathrm{GA}_{3} 250 \mathrm{ppm}$. Improved physiological activity was observed with the application of RDF $50 \%$ in combination with Poultry Manure 50\% which has increased uptake of water which led to proper maintenance of water conducting tissue. These results were in accordance with the earlier findings of Nagaraja and Gowda (1998), Kumar and Singh (2004), Sagar et al., (2005) and Panwar et al., (2006) in cut tuberose. 
Table.1 Effect of pre-harvest management practices on water uptake and transpiration loss of water of cut tuberose cv. Suvasini

\begin{tabular}{|c|c|c|c|c|c|c|c|c|c|c|c|c|}
\hline \multirow{3}{*}{ Treatments $(\mathbf{T})$} & \multicolumn{12}{|c|}{ Days (D) } \\
\hline & \multicolumn{6}{|c|}{ Water uptake (g) } & \multicolumn{6}{|c|}{ Transpiration loss of water $(\mathrm{g})$} \\
\hline & $2^{\text {nd }}$ & $4^{\text {th }}$ & $6^{\text {th }}$ & $8^{\text {th }}$ & $10^{\text {th }}$ & Mean & $2^{\text {nd }}$ & $4^{\text {th }}$ & $6^{\text {th }}$ & $8^{\text {th }}$ & $10^{\text {th }}$ & Mean \\
\hline $30 \mathrm{~cm} \times 30 \mathrm{~cm}+>3.0 \mathrm{~cm}+6.0 \mathrm{~cm}\left(\mathrm{~T}_{1}\right)$ & 35.10 & 15.17 & 08.80 & 2.20 & 0.70 & $\mathbf{1 1 . 8 4}$ & 17.83 & 14.45 & 12.60 & 11.55 & 10.03 & 13.29 \\
\hline $45 \mathrm{~cm} \times 30 \mathrm{~cm}+>3.0 \mathrm{~cm}+6.0 \mathrm{~cm}\left(\mathrm{~T}_{2}\right)$ & 35.63 & 17.43 & 07.13 & 1.50 & 0.30 & $\mathbf{1 2 . 9 5}$ & 18.17 & 16.40 & 14.87 & 13.60 & 10.47 & 14.70 \\
\hline $\mathrm{GA}_{3} 250 \mathrm{ppm}$ Foliar spraying $\left(\mathrm{T}_{3}\right)$ & 38.60 & 21.13 & 12.57 & 4.13 & 1.80 & 16.47 & 26.85 & 21.60 & 20.20 & 18.77 & 13.40 & 20.16 \\
\hline NAA $250 \mathrm{ppm}$ Foliar spraying $\left(\mathrm{T}_{4}\right)$ & 34.15 & 11.57 & 05.83 & 1.47 & 0.25 & $\mathbf{1 0 . 6 5}$ & 14.05 & 12.40 & 11.20 & 10.00 & 9.00 & $\mathbf{1 1 . 3 3}$ \\
\hline RDF 50\% + Poultry Manure 50\% $\left(\mathrm{T}_{5}\right)$ & 35.27 & 20.34 & 14.90 & 5.63 & 2.10 & 14.79 & 17.54 & 17.53 & 15.27 & 14.87 & 11.81 & 15.60 \\
\hline RDF $50 \%+$ Poultry Manure $25 \%+$ Neem Cake $25 \%\left(\mathrm{~T}_{6}\right)$ & 33.13 & 19.43 & 09.38 & 3.08 & 0.87 & 13.18 & 16.75 & 17.53 & 15.10 & 14.20 & 11.70 & 15.06 \\
\hline Control $\left(\mathrm{T}_{7}\right)$ & 15.45 & 10.10 & 05.27 & 0.43 & 0.07 & 06.26 & 12.05 & 10.80 & 9.90 & 6.40 & 2.43 & $\mathbf{0 8 . 3 2}$ \\
\hline Mean & 32.48 & 16.43 & 09.13 & 2.63 & 0.87 & & 17.60 & 15.96 & 14.16 & 12.77 & 9.83 & \\
\hline Factor & \multicolumn{3}{|c|}{ SEd+ } & \multicolumn{3}{|c|}{ CD at $5 \%$} & \multicolumn{3}{|c|}{ SEd+ } & \multicolumn{3}{|c|}{ CD at $5 \%$} \\
\hline Treatments $(\mathrm{T})$ & \multicolumn{3}{|c|}{0.08} & \multicolumn{3}{|c|}{0.18} & \multicolumn{3}{|c|}{0.13} & \multicolumn{3}{|c|}{0.24} \\
\hline Days (D) & \multirow{2}{*}{\multicolumn{3}{|c|}{0.07}} & \multicolumn{3}{|c|}{0.15} & \multirow{2}{*}{\multicolumn{3}{|c|}{0.09}} & \multicolumn{3}{|c|}{0.20} \\
\hline$(\mathrm{T} \times \mathrm{D})$ & & & & \multicolumn{3}{|c|}{0.41} & & & & \multicolumn{3}{|c|}{0.54} \\
\hline
\end{tabular}

Table.2 Effect of pre-harvest management practices on water balance and water loss to uptake ratio of cut tuberose cv. Suvasini

\begin{tabular}{|c|c|c|c|c|c|c|c|c|c|c|c|c|}
\hline \multirow{3}{*}{ Treatments $(\mathbf{T})$} & \multicolumn{12}{|c|}{ Days (D) } \\
\hline & \multicolumn{6}{|c|}{ Water Balance (g) } & \multicolumn{6}{|c|}{ Water loss to uptake ratio } \\
\hline & $2^{\text {nd }}$ & $4^{\text {th }}$ & $6^{\text {th }}$ & $8^{\text {th }}$ & $10^{\text {th }}$ & Mean & $2^{\text {nd }}$ & $4^{\text {th }}$ & $6^{\text {th }}$ & $8^{\text {th }}$ & $10^{\text {th }}$ & Mean \\
\hline $30 \mathrm{~cm} \times 30 \mathrm{~cm}+>3.0 \mathrm{~cm}+6.0 \mathrm{~cm}\left(\mathrm{~T}_{1}\right)$ & $\begin{array}{c}32.77 \\
(17.27) \\
\end{array}$ & $\begin{array}{l}17.22 \\
(1.72) \\
\end{array}$ & $\begin{array}{c}11.70(- \\
3.80)\end{array}$ & $\begin{array}{c}6.15(- \\
9.35) \\
\end{array}$ & $\begin{array}{c}6.17 \\
(-9.33) \\
\end{array}$ & $\begin{array}{c}14.80 \\
(-0.70) \\
\end{array}$ & 0.51 & 0.95 & 1.43 & 5.25 & 14.33 & 4.49 \\
\hline $45 \mathrm{~cm} \times 30 \mathrm{~cm}+>3.0 \mathrm{~cm}+6.0 \mathrm{~cm}\left(\mathrm{~T}_{2}\right)$ & $\begin{array}{c}32.97 \\
(17.47)\end{array}$ & $\begin{array}{l}16.53 \\
(1.03)\end{array}$ & $\begin{array}{c}7.76(- \\
7.74) \\
\end{array}$ & $\begin{array}{c}3.40(- \\
12.1)\end{array}$ & $\begin{array}{c}5.33 \\
(-10.17) \\
\end{array}$ & $\begin{array}{c}13.20 \\
(-2.18)\end{array}$ & 0.51 & 0.94 & 2.09 & 9.07 & 34.93 & 9.51 \\
\hline $\mathrm{GA}_{3} 250 \mathrm{ppm}$ Foliar spraying $\left(\mathrm{T}_{3}\right)$ & $\begin{array}{c}27.25 \\
(11.75) \\
\end{array}$ & $\begin{array}{c}15.03(- \\
0.47) \\
\end{array}$ & $\begin{array}{c}7.87(- \\
7.63)\end{array}$ & $\begin{array}{l}0.86(- \\
14.64) \\
\end{array}$ & $\begin{array}{l}3.90(- \\
11.16) \\
\end{array}$ & $\begin{array}{c}10.98(- \\
4.52)\end{array}$ & 0.70 & 1.02 & 1.61 & 4.54 & 7.45 & 3.06 \\
\hline NAA 250 ppm Foliar spraying $\left(\mathrm{T}_{4}\right)$ & $\begin{array}{c}34.60 \\
(19.10) \\
\end{array}$ & $\begin{array}{c}14.67(- \\
0.83)\end{array}$ & $\begin{array}{c}10.13(- \\
5.37)\end{array}$ & $\begin{array}{c}6.97(- \\
8.53)\end{array}$ & $6.75(-8.75)$ & $\begin{array}{c}14.62(- \\
0.88)\end{array}$ & 0.41 & 1.07 & 1.92 & 6.80 & 36.02 & 9.24 \\
\hline RDF $50 \%$ + Poultry Manure $50 \%\left(\mathrm{~T}_{5}\right)$ & $\begin{array}{c}33.24 \\
(17.74)\end{array}$ & $\begin{array}{l}17.31 \\
(1.81)\end{array}$ & $\begin{array}{c}15.13(- \\
0.37)\end{array}$ & $\begin{array}{l}6.26(- \\
9.24)\end{array}$ & $5.79(-9.71)$ & $\begin{array}{l}15.55 \\
(0.05)\end{array}$ & 0.50 & 0.91 & 1.02 & 2.64 & 5.62 & 2.14 \\
\hline RDF 50\% + Poultry Manure 25\% + Neem Cake 25\% $\left(\mathrm{T}_{6}\right)$ & $\begin{array}{c}31.88 \\
(16.38) \\
\end{array}$ & $\begin{array}{l}17.40 \\
(1.90)\end{array}$ & $\begin{array}{c}9.78(- \\
5.72) \\
\end{array}$ & $\begin{array}{l}4.40(- \\
11.10) \\
\end{array}$ & $\begin{array}{l}4.67(- \\
10.83) \\
\end{array}$ & $\begin{array}{c}13.63(- \\
1.87)\end{array}$ & 0.51 & 0.90 & 1.61 & 4.61 & 13.46 & 4.22 \\
\hline Control $\left(\mathrm{T}_{7}\right)$ & $\begin{array}{l}18.90 \\
(3.40) \\
\end{array}$ & $\begin{array}{c}14.79(- \\
0.71) \\
\end{array}$ & $\begin{array}{c}10.87(- \\
4.63) \\
\end{array}$ & $\begin{array}{c}9.54(- \\
5.96) \\
\end{array}$ & $\begin{array}{c}13.14(- \\
2.36) \\
\end{array}$ & $\begin{array}{c}13.45(- \\
2.05)\end{array}$ & 0.78 & 1.07 & 1.89 & 14.77 & 36.51 & 11.00 \\
\hline Mean & $\begin{array}{c}30.23 \\
(14.73) \\
\end{array}$ & $\begin{array}{l}16.14 \\
(0.64)\end{array}$ & $\begin{array}{c}10.46(- \\
5.04)\end{array}$ & $\begin{array}{l}5.37(- \\
10.13) \\
\end{array}$ & $6.54(-8.96)$ & & 0.56 & 0.98 & 1.65 & 6.81 & 21.19 & \\
\hline Factor & \multicolumn{3}{|c|}{ SEd+ } & \multicolumn{3}{|c|}{ CD at 5\% } & \multicolumn{3}{|c|}{ SEd+ } & \multicolumn{3}{|c|}{ CD at $5 \%$} \\
\hline Treatments $(\mathrm{T})$ & \multirow{2}{*}{\multicolumn{3}{|c|}{0.217}} & \multirow{2}{*}{\multicolumn{3}{|c|}{0.434}} & \multirow{2}{*}{\multicolumn{3}{|c|}{0.187}} & \multirow{2}{*}{\multicolumn{3}{|c|}{$\begin{array}{l}0.375 \\
0.317\end{array}$}} \\
\hline Days (D) & \multirow{2}{*}{\multicolumn{3}{|c|}{$\begin{array}{l}0.184 \\
0.486\end{array}$}} & & & & \multirow{2}{*}{\multicolumn{3}{|c|}{$\begin{array}{l}0.158 \\
0.296\end{array}$}} & & & \\
\hline (T x D) & & & & \multicolumn{3}{|c|}{$\begin{array}{ll}0.367 \\
0.971\end{array}$} & & & & \multicolumn{3}{|c|}{$\begin{array}{l}0.511 \\
0.838\end{array}$} \\
\hline
\end{tabular}

Parenthesis represents the original value.

The data was analysed by uniform addition of a base value of 15.5 to all the values. 
Table.3 Effect of pre-harvest management practices on fresh weight change and electrolyte leakage of cut tuberose cv. Suvasini

\begin{tabular}{|c|c|c|c|c|c|c|c|c|c|c|c|c|c|}
\hline \multirow{3}{*}{ Treatments $(\mathbf{T})$} & \multicolumn{13}{|c|}{ Days (D) } \\
\hline & \multicolumn{6}{|c|}{ Fresh weight change } & \multicolumn{7}{|c|}{ Electrolyte Leakage (\%) } \\
\hline & $2^{\text {nd }}$ & $4^{\text {th }}$ & $6^{\text {th }}$ & $8^{\text {th }}$ & $10^{\text {th }}$ & Mean & $\mathbf{0}^{\text {th }}$ & $2^{\text {nd }}$ & $4^{\text {th }}$ & $6^{\text {th }}$ & $8^{\text {th }}$ & $10^{\text {th }}$ & Mean \\
\hline $30 \mathrm{~cm} \times 30 \mathrm{~cm}+>3.0 \mathrm{~cm}+6.0 \mathrm{~cm}\left(\mathrm{~T}_{1}\right)$ & 81.40 & 69.97 & 62.53 & 52.13 & 44.75 & 62.16 & 17.66 & 28.45 & 34.90 & 44.37 & 62.52 & 82.15 & 45.01 \\
\hline $45 \mathrm{~cm} \times 30 \mathrm{~cm}+>3.0 \mathrm{~cm}+6.0 \mathrm{~cm}\left(\mathrm{~T}_{2}\right)$ & 90.70 & 70.87 & 64.47 & 56.30 & 47.90 & 66.05 & 16.65 & 27.41 & 32.11 & 40.71 & 59.14 & 81.37 & 42.90 \\
\hline $\mathrm{GA}_{3} 250 \mathrm{ppm}$ Foliar spraying $\left(\mathrm{T}_{3}\right)$ & 94.70 & 80.80 & 70.53 & 61.81 & 57.20 & 73.01 & 13.93 & 20.96 & 28.38 & 36.62 & 52.34 & 70.00 & 37.04 \\
\hline NAA $250 \mathrm{ppm}$ Foliar spraying $\left(\mathrm{T}_{4}\right)$ & 59.97 & 58.40 & 53.76 & 49.87 & 39.83 & 52.37 & 18.35 & 32.02 & 36.89 & 48.70 & 71.82 & 84.34 & 48.69 \\
\hline RDF 50\% + Poultry Manure 50\% $\left(\mathrm{T}_{5}\right)$ & 99.03 & 86.80 & 74.40 & 69.41 & 62.77 & 78.48 & 13.00 & 17.64 & 26.43 & 32.46 & 47.54 & 64.53 & 33.60 \\
\hline $\begin{array}{l}\text { RDF 50\%+ Poultry Manure 25\% + Neem Cake } \\
25 \%\left(\mathrm{~T}_{6}\right)\end{array}$ & 87.10 & 72.37 & 68.40 & 58.77 & 49.43 & 67.21 & 14.97 & 24.65 & 30.54 & 38.38 & 55.08 & 74.54 & 39.69 \\
\hline Control $\left(\mathrm{T}_{7}\right)$ & 44.13 & 40.57 & 36.50 & 32.13 & 23.53 & 35.37 & 20.68 & 36.89 & 40.23 & 56.84 & 76.61 & 86.94 & $\mathbf{5 3 . 0 3}$ \\
\hline Mean & 79.58 & 68.54 & 61.51 & 54.35 & 46.49 & & 16.46 & 26.86 & 32.78 & 42.58 & 60.76 & $\mathbf{7 7 . 7 0}$ & \\
\hline Factor & \multicolumn{3}{|c|}{ SEd+ } & \multicolumn{3}{|c|}{ CD at $5 \%$} & \multicolumn{3}{|c|}{ SEd+ } & \multicolumn{4}{|c|}{ CD at $5 \%$} \\
\hline Treatments $(\mathrm{T})$ & \multirow{2}{*}{\multicolumn{3}{|c|}{$\begin{array}{l}0.234 \\
0.196\end{array}$}} & \multirow{2}{*}{\multicolumn{3}{|c|}{$\begin{array}{l}0.463 \\
0.391\end{array}$}} & \multirow{2}{*}{\multicolumn{3}{|c|}{$\begin{array}{l}0.12 \\
0.10\end{array}$}} & \multirow{2}{*}{\multicolumn{4}{|c|}{$\begin{array}{l}0.22 \\
020\end{array}$}} \\
\hline Days (D) & & & & & & & \multirow{2}{*}{\multicolumn{3}{|c|}{$\frac{0.10}{0.28}$}} & & & & \\
\hline$(\mathrm{T} \times \mathrm{D})$ & \multicolumn{3}{|c|}{$\begin{array}{l}0.190 \\
0.194\end{array}$} & \multicolumn{3}{|c|}{\begin{tabular}{|l|}
0.391 \\
0.391
\end{tabular}} & & & & \multicolumn{4}{|c|}{$\begin{array}{l}0.20 \\
0.54\end{array}$} \\
\hline
\end{tabular}

Table.4 Effect of pre-harvest management practices on per cent of opened flowers and vase life of cut tuberose cv. Suvasini

\begin{tabular}{|c|c|c|c|c|c|c|c|c|}
\hline \multirow{3}{*}{ Treatments $(\mathbf{T})$} & \multicolumn{6}{|c|}{ Days (D) } & \multirow{3}{*}{\multicolumn{2}{|c|}{ Vase life }} \\
\hline & \multicolumn{6}{|c|}{ Per cent of opened florets } & & \\
\hline & $2^{\text {nd }}$ & $4^{\text {th }}$ & $6^{\text {th }}$ & $8^{\text {th }}$ & $10^{\text {th }}$ & Mean & & \\
\hline $30 \mathrm{~cm} \times 30 \mathrm{~cm}+>3.0 \mathrm{~cm}+6.0 \mathrm{~cm}\left(\mathrm{~T}_{1}\right)$ & 8.33 & 20.75 & 25.75 & 40.63 & 47.73 & 33.06 & \multicolumn{2}{|c|}{11.59} \\
\hline $45 \mathrm{~cm} \times 30 \mathrm{~cm}+>3.0 \mathrm{~cm}+6.0 \mathrm{~cm}\left(\mathrm{~T}_{2}\right)$ & 13.88 & 25.55 & 32.53 & 42.56 & 48.21 & 37.24 & \multicolumn{2}{|c|}{11.88} \\
\hline $\mathrm{GA}_{3} 250 \mathrm{ppm}$ Foliar spraying $\left(\mathrm{T}_{3}\right)$ & 24.47 & 30.13 & 38.00 & 48.21 & 62.39 & 37.80 & \multicolumn{2}{|c|}{12.45} \\
\hline NAA 250 ppm Foliar spraying $\left(T_{4}\right)$ & 6.00 & 7.74 & 8.56 & 12.25 & 15.12 & 9.93 & \multicolumn{2}{|c|}{10.11} \\
\hline RDF 50\% + Poultry Manure $50 \%\left(\mathrm{~T}_{5}\right)$ & 27.08 & 34.08 & 42.75 & 54.64 & 64.74 & 37.89 & \multicolumn{2}{|c|}{13.67} \\
\hline $\begin{array}{l}\text { RDF } 50 \%+\text { Poultry Manure } 25 \%+\text { Neem Cake } \\
25 \%\left(\mathrm{~T}_{6}\right)\end{array}$ & 15.75 & 28.33 & 36.46 & 45.75 & 59.22 & 37.59 & \multicolumn{2}{|c|}{12.06} \\
\hline Control $\left(\mathrm{T}_{7}\right)$ & 5.00 & 6.60 & 7.45 & 10.08 & 11.56 & 08.14 & \multicolumn{2}{|c|}{9.34} \\
\hline Mean & 14.36 & 21.88 & 27.36 & 36.30 & 44.14 & & \multicolumn{2}{|c|}{11.58} \\
\hline Factor & \multicolumn{3}{|c|}{ SEd+ } & \multicolumn{3}{|c|}{ CD at $5 \%$} & SEd+ & CD at $5 \%$ \\
\hline Treatments $(\mathrm{T})$ & \multicolumn{3}{|c|}{0.15} & \multicolumn{3}{|c|}{0.27} & \multirow{3}{*}{0.24} & \multirow{3}{*}{0.46} \\
\hline Days (D) & \multicolumn{3}{|c|}{0.12} & \multicolumn{3}{|c|}{0.23} & & \\
\hline$(\mathrm{T} \times \mathrm{D})$ & \multicolumn{3}{|c|}{0.32} & \multicolumn{3}{|c|}{0.61} & & \\
\hline
\end{tabular}


The data presented in Table 3 has indicated that application of RDF $50 \%$ in combination with Poultry Manure $50 \%$ recorded significantly highest fresh weight of the flower spikes (78.48 g) followed by foliar application of $\mathrm{GA}_{3} 250 \mathrm{ppm}(73.01 \mathrm{~g})$. Among the days, significantly highest fresh weight of cut tuberose spikes was recorded on day 2, whereas, significantly lowest fresh weight was recorded on day 10. A gradual reduction in the fresh weight change of flower spikes was observed with passage of time at each successive interval of observation recorded during the vase life period. Interaction effect between days and treatments was found significant with regard to fresh weight change. Application of RDF $50 \%$ in combination with Poultry Manure $50 \%$ recorded significantly highest fresh weight on all the days of observation recorded followed by flower spikes collected from foliar application of $\mathrm{GA}_{3} 250 \mathrm{ppm}$. Increased water relations in the floral tissue might have led to an increase in the metabolic activity without loss of quality. Sucrose is the main carbohydrate source which decreases water potential and thus improves water uptake and fresh weight of flower spikes. Similar kind of observation was reported earlier by Namita $e t$ al., (2006) in cut gladiolus spikes, Barman and Rajni (2006) in cut rose and Bhaskar et al., (2000) and Varu and Barad (2008) in tuberose. Increased rate of water uptake and reduced rate of transpiration led to an increase in the water balance which has led to retention of fresh weight of flower spikes (Neelima and Singh, 2017).

The data presented in Table 3 has indicated that among the treatments application of RDF $50 \%$ in combination with Poultry Manure $50 \%$ recorded significantly lowest electrolytes leakage $(33.60 \%)$ followed by foliar application of $\mathrm{GA}_{3} 250 \mathrm{ppm}$ (37.04\%). Among the days, significantly highest rate of electrolyte leakage was observed on day 10 , whereas, significantly lowest rate of electrolyte leakage was observed on day 2. A gradual increase in the electrolytes leakage was observed with passage of time at each successive interval of observation recorded during the vase life period. The interaction effect between treatments and days was found significant. Among the combinations, application of RDF $50 \%$ in combination with Poultry Manure $50 \%$ has recorded significantly lowest electrolytes leakage on all the days of observation recorded, whereas, control recorded significantly highest electrolytes leakage. An increase in the rate of water uptake and a significant decrease in the rate of transpiration loss of water led to an improvement in the water balance which might have contributed to the membrane integrity of the cell there by a reduction was observed in the leakage of electrolytes in the petal tissue. Neelima and Singh (2017) also expressed similar kind of opinion.

Data presented in Table 4 signifies that flower spikes collected from application of RDF $50 \%$ in combination with Poultry Manure $50 \%$ recorded significantly highest per cent of opened florets from $2^{\text {nd }}$ day to $10^{\text {th }}$ day of experimentation followed by spikes collected from foliar application of $\mathrm{GA}_{3} 250 \mathrm{ppm}$. Flower spikes harvested from the plots treated with RDF $50 \%$ in combination with Poultry Manure 50\% recorded significantly longest vase life (13.67 days) followed by spikes collected from foliar application of $\mathrm{GA}_{3} 250$ ppm (12.45 days). The reason might be due to the fact that flower spikes collected from RDF $50 \%$ in combination with Poultry Manure $50 \%$ treated plants might have accumulated sufficient food material required for their regular physiological activities hence opening of florets was found significantly highest. Further, prevention of vascular blockage and presence of higher content of soluble sugars in the floral tissue also would have contributed to increased per cent of opened 
florets (Bhaskar et al., 2000). Further, increased rate of water uptake and reduced rate of transpiration loss of water might have led to improved water balance in the floral tissue thereby recorded an increase in the fresh weight change thus leading to a reduction in the leakage of electrolytes which might have contributed to increased per cent of opened florets as well as vase life. The external application of sucrose and $\mathrm{Al}_{2}\left(\mathrm{SO}_{4}\right)_{3}$ as sources of carbohydrate and antimicrobial compound in the vase solution might have reduced the stem blockage and maintained the continuity of water conductivity. Presence of sucrose in the vase solution prevents moisture stress in the floral tissue and increases the osmotic adjustment to improve water absorption, hence maintained turgidity for better opening of florets. The present results were in conformity with the earlier findings of Kumar et al., (2007) and Varu and Barad (2008) in tuberose and Namita et al., (2006) in gladiolus.

\section{References}

Anjupal, K.S. and Srivastava, R. 2003. Effect of floral preservatives on postharvest management in gladiolus spikes. Journal of Ornamental Horticulture 6(4): 367-371.

Barman, D. and Rajni, K. 2006. Effect of chemicals and postharvest life of cut rose cultivar First Red. Journal of Ornamental Horticulture, 9(4): 262265.

Bhaskar, V.V., Rao, P.V. and Reddy, Y.N. 2000. Effect of certain chemicals on the postharvest vase life of cut tuberose (Polianthes tuberosa L.) cv. Double. Journal of Ornamental Horticulture 3(1): 6-11.

Das, P. 1988. Mode of action of metal salts on vase life of cut gladioli. Acta Horticulturae, 266: 307-317.

Halevy, A.H. and Mayak, S. 1979.
Senescence and postharvest physiology of cut flowers part-I. Horticultural Reviews, 1: 204-235.

Halevy, A.H. and Mayak, S. 1981. Senescence and postharvest physiology of cut flowers part-II. Horticultural Reviews, 3: 59-143.

Krishnappa, K.S., Reddy, S.N. and Anjanappa. 2004. Effect of floral preservatives on the vase life of carnation cut flower cultivars. Karnataka Journal of Agricultural Sciences, 13: 395-400.

Kumar, B., Malik, S., Mukesh, K., Singh, M.K, and Kumar V. 2007. Postharvest quality and vase life of tuberose (Polianthes tuberosa Linn.) cut spikes as affected by vase chemicals. Journal of Ornamental Horticulture 10(4): 275277.

Kumar, J. and Singh, D. 2004. Postharvest life of tuberose Pearl Double spike as effected by $\mathrm{GA}_{3}$, NAA and sucrose. Journal of Ornamental Horticulture, 7(2): 188-191.

Lal, S.D., Shah, A. and Pant, C.C. 1990. Effect of certain chemical substances on vase life and quality of gladiolus cv. Silver Horn. Progressive Horticulture. 89: 726-729.

Larsen, F.E. and Froehlich, M. 1969. The influence of 8-Hydroxy quinoline citrate, $\mathrm{N}$-dimethyl amino succinamic acid and sucrose on respiration and water flow in 'Redsim' carnation in relation to flower senescence. Journal of American Society for Horticultural Sciences 87: 548-563.

Mayak, S, Brardo, B, Gvilli, A. and Halevy, A.H. 1973. Improvement of opening of cut gladiolus flowers by pre treatment with high sucrose concentration. Scientia Horticulturae, 1: 357-365.

Mukhopadhyay, T.P. 1982. Effect of chemicals on the floral development and vase life of tuberose. South Indian 
Horticulture, 30(4): 281-284.

Nagaraja, G.S. and Gowda, J.V.N. 1998. Influence of growth regulators on vase life of tuberose cv. Single. Current Research, UAS, Bangalore, 27(7-8): 147-148.

Namita, Ramesh, K. and Kushal, S. 2006. Effect of pre storage pulsing on storage life of gladiolus cut spikes. Journal of Ornamental Horticulture, 9(4): 258261.

Neelima, P. and Singh, A. 2017. Post-harvest quality and physiology of gerbera flowers as influenced by bio-fertilizers, chemicals and organic growth regulators. Research on Crops, 18(1): 116-122.

Padaganur, V.G., Mokashi, A.N. and Patil, V.S. 2005. Effect of Growth Regulators on Growth and Yield of Tuberose cv. Single. Karnataka Journal of Agricultural Sciences, 18(2): 469-473.

Panse, V.G. and Sukhatme, P.V. 1985. Statistical Methods for Agricultural Workers, $4^{\text {th }}$ edition, ICAR, New Delhi, pp. 347.

Panwar, R.D., Sindhu, S.S., Sharma, J.R. and Gupta, R.B. 2006. Response of bulb dipping in gibberellic acid on growth, flowering and bulb production in tuberose (Polianthes tuberosa Linn.), Journal of Ornamental Horticulture 9(1): 49-51.

Poovaiah, B.W. 1973. Deferral of leaf senescence with calcium. Plant Physiology. 52: 236-239.

Ranjan, S., Vishen, V.S. and Satish, C. 2007.
Effect of Azotobacter and organic manures on postharvestcharacteristics of tuberose (Polianthes tuberosa L.) cv. Double. Pantnagar Journal of Research 5(1): 54-55.

Sadhu, M.K, and Bose, T.K. 1978. Tuberose for most artistic garlands. Indian Journal of Horticulture 15: 17-20.

Sagar, N.N., Kawar, K., Deshmukh, V.J., Deshmukh, M. and Lokhand, B.S. 2005. Effect of pre planting growth regulator treatment of bulks on growth and flowering of tuberose. Orissa Journal of Horticulture 33(1): 39-42.

Saini, R.S., Yamdagni, R. and Sharma, S.K. 1994. Effect of some chemicals on the vase life of tuberose cv. Single. South Indian Horticulture 42(6): 376-378.

Samia, I, Habib, U. and Nauman, K. 2012. Effect of different potting media combinations on growth and vase life of tuberose (Polianthes tuberosa Linn.). Pakisthan Journal of Agricultural Sciences 49(2): 121-125.

Van Doorn, W.G. 2004. Water relations of cut flowers. Horticultural Reviews 18: 1-68.

Varu, D.K. and Barad, A.V. (2008). Effect of floral preservatives on quality and vase life of cut flowers tuberose (Polianthes tuberosa L.) cv. Double. The Asian Journal of Horticulture 3(1): 169-172.

Wakada, A.E., Herner, R.C., Kader, A.A., Ramani, R.J. and Staby, G.L. 1984. Terminology for the description of developmental stages of horticultural crops. Hort. Science 19: 20-21.

\section{How to cite this article:}

Suseela, T., V. Vijaya Bhaskar, R. Chandrasekhar and Umakrishna, K. 2017. Effect of PreHarvest Management Practices on the Postharvest Vase Life of Cut Tuberose cv. Suvasini. Int.J.Curr.Microbiol.App.Sci. 6(12): 2504-2512. doi: https://doi.org/10.20546/ijcmas.2017.612.291 